\title{
Combining planning and the market: an analysis of the Government strategy towards higher education in the Netherlands
}

\begin{abstract}
Frans A. van Vught
University of Twente, P. O. Box 217, 7500 AE Enschede, The Netherlands

This article discusses and analyses the government strategy towards higher education in the Netherlands as it has been designed and implemented since the publication of an influential policy document in 1985 . This strategy intends to be a significant break with the traditional government attitude of detailed planning and control. It tries to strengthen the autonomy of the higher education institutions and to enlarge their adaptability to the needs of society. In this article the government strategy is characterized as a combination of two fundamental mechanisms of coordination: planning and the market. It is argued that the strategy shows that the Dutch government tries to address both market and non-market failures. However, by doing so, it has created a mixed bag of policies and instruments, demonstrating that government has not yet abandoned its confidence in its own capacity to successfully steer the higher education system. (C) 1997 International Association of Universities
\end{abstract}

Key words: Planning, market, institutional autonomy, coordination, market and non-market failures

\section{INTRODUCTION}

In 1985 the Dutch Ministry of Education and Science published a policy document which brought about a major change in the long-standing relationship between government and higher education in the Netherlands. The name of the policy document was: HOAK ("Hoger Onderwijs: Autonomie en Kwaliteit"; "Higher Education: Autonomy and Quality"). In HOAK the Ministry presented a completely new strategy towards higher education. This new strategy implies a significant break with the traditional government attitude which was one of detailed planning and control. In the traditional strategy government tried to steer the higher education system with stringent regulations and extensive control mechanisms. In this strategy, which dates back to the beginning of the 19th century, government saw itself as an omnipotent actor able to guide the higher education system according to its own objectives.

The new government strategy, which since 1985 has been further elaborated (see below), appears to be an important change in Dutch higher education. By strengthening the autonomy of the higher education institutions (both the 13 universities and the 65 higher vocational training schools: HBO institutions), the government seeks to create fruitful conditions for the enlargement of the adaptive capacity and flexibility of these institutions to respond to the needs of society. Furthermore, the government 
expects to be able to raise the levels of quality and differentiation of the system (Ministry of Education and Science, 1985).

The new strategy includes a major step towards greater institutional autonomy and self-responsibility. Government itself is stepping back. The assumption behind this new strategy is that an increase in institutional autonomy improves the overall performance of the system. The higher education institutions need to have greater freedom to shape their own activities. They have to be offered more responsibility in the fields of education and research. Detailed governmental regulations concerning these activities should be abolished. The increase of institutional autonomy is expected to make the system as a whole more responsive to the rapidly changing demands of modern society. More autonomy at the institutional level is assumed to result in more scientific and technological breakthroughs and in better educated professionals.

There has been some debate in the Netherlands as to what extent the HOAK policy document is a move away from traditional government planning to a market-like approach to higher education coordination and whether a market-like approach would be fruitful (van Vught, 1987, 1989; Mertens et al., 1988). In this article I will present an analysis of the new government strategy towards higher education in the Netherlands. My conclusion will show that this new strategy is a step towards more market-coordination in higher education, but that it is not a complete abandonment of governmental planning in favor of "the market". The new government strategy towards higher education in the Netherlands appears to be a carefully designed combination of two basically different coordination mechanisms.

\section{A LONG HISTORY OF GOVERNMENTAL PLANNING}

When the various nations in Europe developed as clearly identifiable political entities, education generally became the responsibility of the state. This certainly was the case in the Netherlands. Contrary to the situation when the country was still a republic of united provinces, during the first years of the Kingdom of the Netherlands, the state deliberately occupied itself with higher education. In 1814 King William I declared the large number of universities that existed before the French occupation could not be maintained (Florax, 1992, pp. 30-38). The universities became directly dependent on the state, which decided their budgets and appointed their governing administrators. The responsibilities of the previously autonomous "Colleges of Curators" were reduced to the implementation of governmental dccisions. Professors became civil servants (Cohen, 1982).

At the beginning of the nineteenth century, the government claimed for itself the responsibility of higher education, a responsibility which was for the first time stipulated in the Higher Education Act of 1876. Since that time (and until the HOAK policy document of 1985) the government has tried to "plan" higher education. Although a certain respect existed for the autonomy of universities, the government saw it as its task to make sure that they would behave according to the rules set by the government.

This attitude is clearly found in the well-nigh endless number of policy documents produced by the Ministry of Education and Science during the $1970 \mathrm{~s}$ and early $1980 \mathrm{~s}$. Time and again the higher education system of the Netherlands overflowed with documents, often with intriguing and poetic titles. As a matter of course, all these documents subscribed to the need of the state to plan and control higher education. 
Some documents explicitly addressed the wish to create a new planning structure or make new sets of planning procedures. Two clear examples are the so-called McKinsey report in 1971 on a comprehensive planning system in higher education and the 1975 government document called "Planning for Higher Education" written by a special task force of civil servants.

Along with this assumed self-evident focus on governmental planning came a long list of successive planning systems that, has been described as a "backward hopping procession of Echternach" (Camps, 1984/85). Looking back at the many different planning procedures and other institutional arrangements that existed in Dutch higher education until the second half of the 1980 s, one cannot but conclude that government strategy towards higher education, like the procession in the medieval town of Echternach, took three steps forward, followed by two steps backward. Again and again, new planning procedures were introduced in the hope that by these new procedures the negative effects of their predecessors ones would be overcome. However, until the HOAK policy document whether the higher education system in the Netherlands needed to be planned and controlled by the government, was never in doubt.

The HOAK policy document changed all this. The government indicated that it wanted to give up its traditional controlling strategy. It intended to enlarge the autonomy of higher education institutions and, by doing so, to increase the adaptability and the flexibility of the whole higher education system.

A crucial question is whether this new strategy can be characterized as a marketlike approach to higher education. To answer that question I will first briefly explore the normative and theoretical foundations of the coordinative capacities of both planning and the market.

\section{COORDINATION BY MEANS OF PLANNING}

The idea of planning is rooted deeply in Western culture. It goes back to Plato and is directly related to Cartesian rationalism. Planning implies a perspective in which order is created by cultivating Reason. It is the objective of Reason to find the "eternal forms" of which our everyday appearances only are shadowy copies. By practicing Reason we will be able to produce knowledge about the eternal order of things, by which we will then be able to control the world according to our own objectives.

Based on this perspective, and inspired by the wish to rationalize man and society, from the 1930s on, many committed intellectuals have tried to institutionalize mechanisms of social coordination by means of planning. A well-known person of this stamp was the Hungarian-German sociologist, Karl Mannheim. According to Mannheim, after the first world war, liberal Western societies were headed towards crisis and disorientation. To prevent these societies from losing their fundamental norms and values, a new rational control system had to be invented. This new control system would be a "planning for freedom", by which a group of "relativ freischwebende" intellectuals would make use of direct and indirect interventions to lead society in the right direction (Mannheim, 1940).

Mannheim argued coordination by means of planning was the inevitable next step in the evolution of Western democracies. Instead of acting like Goethe's fatalistic sorcerer's apprentice, who feared only the phantoms he had created, Mannheim believed we should accept the challenges to create and control social processes. Instead 
of living with the Romantic concept of the status quo, we should dare to understand that only the combination of scientific rationality and political practice would allow us to develop society further (Mannheim, 1940, pp. 239-253).

Mannheim's call still echoes in the literature on planning today. Whether planning is seen as the systemic preparation of policy, or as the well-founded support of decisions (to mention just two general concepts of planning), the emphasis still rests on the use of Reason to transform social systems into a new and better order (Faludi, 1973, pp. 35-42).

When used by governments, coordination by means of planning implies the government's wish to control societal processes. In order to produce better (i.e. more effective and/or more efficient) outcomes, governments design and implement institutional frameworks aimed at influencing the behavior of societal actors. A government making use of planning tries to steer the decisions and actions of specific societal actors according to the objectives the government has set, and by using the instruments the government has at its disposal (Mitnick, 1980). In this strategy much confidence is put in the capabilities of governmental actors and agencies to acquire comprehensive and true knowledge and to make the best decisions. Also, it is a strategy in which governmental actors try to steer other societal actors by using (usually stringent) rules and control mechanisms (van Vught, 1993, pp. 34-37).

\section{MARKET COORDINATION}

The idea of the market is fundamentally different from the idea of planning. It is related to the view that social reality shows a "spontaneous order" (Hayek, 1967, Chap. 4) itself is the result of the implicit, but not intentional dynamics set up by the behavior of a multitude of interrelated actors. As the Scottish philosopher Adam Ferguson (1723-1816) said: "Every step and every movement of the multitude ... are made with equal blindness to the future; and nations stumble upon establishments, which are indeed the result of human action, but not the execution of any human design" (Ferguson, 1996, (orig. 1773) p. 205).

A spontaneous social order is characterized by fragmented knowledge, spread over a large number of actors, but which allows for the coordination of individual decisions and actions. It offers individual actors the advantage of social regularity. By accepting the spontaneous order of developing social rules, individual decision makers are able to limit their decision-making analyses to a relatively small number of alternatives, thus limiting their information and transaction costs.

As the outcome of the many individual decisions and actions, a spontaneous social order automatically produces a certain level of coordination. This coordination is not the intentional outcome of the actions of the omniscient and omnipotent "mastermind". It is rather a "coordination without a coordinator" (Wildavsky, 1979, p. 90), a coordination of the "invisible hand" that creates an accomplishment no one intends. In this sense market coordination is the accidental result of a large number of voluntary decisions taken by a large number of actors.

Compared to government planning, the market is basically different. A key aspect of government planning is the effort of government to design and implement institutional frameworks to influence the behavior of other actors. The market is a type of interaction in which matters are disaggregated and no one is in charge: "... the market is nothing more than an option for each individual to choose among numerous existing 
institutions, or to fashion new arrangements suited to his own situation and taste... The market is simply the freedom to choose among many or still-to-be-created possibilities... The market is no particular set of institutions. Its advantages and disadvantages are due precisely to this fact" (Sowell, 1980, p.41).

\section{THE ASSUMPTIONS OF THE NEW GOVERNMENT STRATEGY}

The new government strategy towards higher education in the Netherlands intends to break away from the long history of government planning. The major HOAK policy document clearly underlines this objective. At the same time the document offers a number of arguments for a new government strategy.

According to the HOAK document, the higher education system of the Netherlands is faced with an increasing variety of demands for its products and services. Because of this, there is an increasing need to innovate in the system, allowing it to become more flexible and responsive to rapidly changing societal conditions. The higher education system should both increase its adaptive capacity and its flexibility (i.e. the pace with which it adapts to changing circumstances). "We have to find mechanisms that stimulate 'the moveability of the system'; we have to increase the higher education system dynamics", argues the HOAK document (Ministry of Education and Science, 1985, pp. 8-11). In order to bring about higher levels of system dynamics, the autonomy of the elements of the system (the higher education institutions) should be increased. Such an increased autonomy will lead to more internal variety of the higher education system, which will be the system's answer to the growing external variety in the demand for its output.

The concept of "variety" appears to be central to HOAK's argument. Unfortunately, the document remains rather vague in defining this concept, but we may assume that, in principle, all possible forms of variety in higher education are included. Since the external variety is increasing, the (internal) variety represented by programs, levels, scale, type of funding, client-orientation, reputation, type of administration, geographical orientation, etc., should also increase (see Birnbaum, 1983).

Variety is one of the central concepts in the theory of cybernetics. Ashby (1956, p. 126) defines variety as the number of distinct elements of a system. According to his "law of requisite variety" full regulation over a system with a certain level of variety can only be produced by a system with at least a similar level of variety: "only variety can destroy variety" (Ashby, 1956, p. 207; van Vught, 1994).

This cybernetic orientation is found in several theories of organization that focus on relationships between organizations and their environments. A notion basic to these theories is the idea that processes of change in open social systems can be explained by the interactions between systems and their environments, in a way similar to the "ecological" or "natural selection" thesis in evolutionary biology (Aldrich, 1979; Hannan and Freeman, 1977, 1989; Pfeffer and Salancik, 1978). Organizations arc assumed to go through the processes of variation, selection, and retention, striving after survival and trying to find an "ecological niche" that allows them to do so.

In higher education such a view suggests that higher education institutions try to adapt to environmental conditions while competing for resources. In many higher education systems the crucial resources are the number of students and of research contracts. They offer the financial means to guarantee survival. In processes of com- 
petition higher education institutions react to the variety in their environment by trying to respond to specific sets of external conditions, thus carving out specialized niches. The more institutions respond differently to the external variety of their environmental conditions, the larger will be the amount of internal variety in the higher education system.

Although this is not clearly indicated, HOAK appears to follow this line of argument. The policy document suggests that the external variety in the environment of the Dutch higher education system is growing and that consequently the internal variety should also increase. In order to allow for such an increase the autonomy of the higher education institutions should be enlarged. The individual organizations of higher education should be given the opportunity to respond to their environment by carving out specialized niches.

Processes of adaptation and competition, of course, are also crucial aspects of market coordination. Coordination through the market is an automatic device because of the adaptive behavior of "producers" reacting to the large variety of wishes and needs of "consumers". From this perspective the (implicit) theoretical notions beneath the new Dutch government strategy in higher education clearly point to a move away from the idea of coordination by means of planning and towards the idea of market coordination. However, as will be argued below, the new strategy only goes half way in this process from planning to market. The HOAK policy document balks at drawing fully the consequences of its own analysis. It offers us a combination of two theoretical models of coordination in which the higher education institutions are assumed to behave like market organizations whilst the government still plays a planning role.

When the new government strategy implied a complete step towards the model of market coordination, the competition between the institutions of higher education should have been as large as possible. The role of government should have been limited to removing market failures (see below).

The new strategy does not follow that logic. On the one hand, HOAK makes several suggestions to increase the influence of the market. It suggests a broader freedom for students to choose the content of their studies. It proposes to abolish detailed regulations regarding educational programs and examinations and to allow the higher education institutions to react freely to educational demands. It offers the higher education institutions the opportunity to create their own quality control system.

On the other hand, however, HOAK also holds onto various instruments of government regulation. The length of study-programs will be limited to 4 years; the propaedeutic phase cannot be longer than one year; there will be a uniform system to assess study-efforts, and higher education institutions will not be allowed to use entrance selection mechanisms. In addition, higher education institutions cannot deviate from the government's personnel policy or develop their own administrative and financial procedures.

Although the autonomy of the higher education institutions is increased, a full operation of the mechanism of market coordination apparently is not allowed. The sovereignty of consumers (students, employers) is hardly addressed by HOAK. In many aspects of their behavior, higher education institutions are confronted with prescribed conditions. The new government strategy as outlined in HOAK is a break with the traditional emphasis on government planning, but it does not abandon the notion of planning. The new strategy is a combination of planning and market 
coordination. It is an "intriguing Janus-head" looking in two directions (Maassen and van Vught, 1988).

\section{FURTHER ELABORATION OF THE STRATEGY}

Since the presentation of the HOAK document in 1985 several things have changed in Dutch higher education policy. But the general government strategy remains founded on this document. The strategy also still shows the combination of planning and market coordination. On the one hand, the Ministry of Education and Science has indicated that it wants to enlarge the autonomy of the higher education institutions. On the other hand, the Ministry has presented some new planning regulations intend to allow government better control over higher education. Both tendencies can be illustrated with the development of Dutch higher education policy since 1985 .

In 1987 HOAK was followed by the introduction of a new overall planning system, introduced as the next step in the development of the new government strategy. The policy document dealing with the new planning system indicates that in the context of the new government strategy a great deal of weight would be given to planning by means of dialogue between the Ministry and the higher education institutions (Ministry of Education and Science, 1987). Both the Ministry and each institution should write down their intentions in the central documents of the new planning system: the governmental plan called HOOP ("Hoger Onderwijs en Onderzoek Plan", Plan for Higher Education and Research) and the institutional development plans. The new planning system resides on a 2-year planning cycle with HOOP being published in the first year and the institutional plans in the second year. The first HOOP was presented in 1988 (after a draft in 1987). Since then every 2 years a new government HOOP has been published. The first institutional plans appeared in 1989. Since the implementation of the new Law on Higher Education and Scientific Research of 1993 (see below) the institutional plans no longer have to be formally offered to the minister. They do have to be published, however.

The new planning system, and certainly many proposals in the various governmental HOOP's, make clear that the Dutch government is of two minds about the way the higher education system should be coordinated. On the one hand, the Ministry aims to enlarge of the influence of market coordination. In the 1988 plan, for instance, it argued that governmental steering in the future will be focused at the so-called "sector-level". Sector is a term introduced by the Ministry to indicate a collection of coherent educational programs (of which ninte are distinguished: Arts, Science, Law, Economics, Health, Behavior and Society, Technology, Education, Agriculture). This general level of steering is supposed to express the wish of government to offer more autonomy to the higher education institutions. The sectors are supposed to indicate the boundaries within which (when they are assigned to them) the institutions are free to act. On the other hand, the first HOOP also announce several new governmental steering instruments. The minister can, for instance, use the so-called "negative statement of funding" if an institutional activity, regarded by government as undesirable, is not modificd or stopped. In a more positive but rather similar sense, the minister has at his disposal the instrument of "selective incentives" which can be used to stimulate developments in the higher education system which, according to the Ministry, are not or insufficiently taking place (Ministry of Education and Science, 1987).

Several other recent policy proposals underline the government wish to develop further the combination of the two coordination mechanisms. 
The new law for higher education ("Wet op het Hoger Onderwijs en Wetenschappelijk Onderzoek": WHW) which came into force on 1 August 1993, was an impressive attempt to abolish the multiplicity of detailed government regulation which remained from before the HOAK policy document era. The new law replaced no fewer than seventeen previously existing Acts (Ministry of Education and Science, 1993).

The WHW underlines that higher education institutions will be free to develop and design their own educational programs. At the same time, it states that the length of the programs should be uniform (4 years) and that entrance selection would not be allowed. Also the earlier suggestion regarding the nine general educational sectors was excised. The current argument is that to limit the government's capabilities to establish and adjust educational programs would hamper the efficient organization of the supply of higher education. In addition the WHW argues that, although the institutions are responsible for the programs, the government can interfere when selfregulation does not occur or when the "macro-efficiency" of the overall system might be harmed.

To protect the macro-efficiency of the higher education system the new law introduces the Central Register for Higher Educational Programmes (CROHO). CROHO is an information system about educational programs. The higher education institutions are supposed to provide the information for the system by reporting on the structure of their programs, the study load, the character of the courses, etc. A program will only receive government funding if it is included in CROHO.

In practice the establishment of this register of programs of course implies a continuation of government planning and control. Without government funding, programs will seldom be continued and without government funding, starting new programs seems to be meaningless (Huisman and Jenniskens, 1994, p. 276).

For the establishment of new educational programs the WHW introduces a special procedure. Institutions intending to start a new program must inform the Ministry about this new initiative. The minister then awaits the advice of a special committee (the Committee for Educational Provision) after which he decides whether the new program will or will not be funded. The "macro-efficiency" of the overall system is again used as a major criterion for making a decision.

Since 1993 the autonomy of the institutions with respect to educational programs appears to have increased slightly. The institutions have been given the opportunity to freely establish the level of tuition, but only for students who no longer are eligible for (government paid) study support. The opportunities to design part-time programs have been enlarged. Also, a proposal has been floated to abolish the uniform length of programs. However, on this last point, institutions may only choose between two alternatives: programs of 4 years or programs of 3 plus 2 years (without additional funding).

The WHW of 1993 also formally established the quality control system in Dutch higher education. Legally, the quality control system is the responsibility of the higher education institutions. The governmental conditions regarding quality control are only procedural: the quality assessments should take place at a regular basis. They should be undertaken in cooperation. They should involve independent experts. The results should be made public and should offer a basis for comparison.

As has been indicated in several publications (Goedegebuure et al., 1990; van Vught and Westerheijden, 1993; Vroeijenstijn and Acherman, 1990; Vroeijenstijn, 1995; Westerheijden et al, 1994) the higher education institutions in the Netherlands (both 
the universities and the HBO-institutions) have been successful in developing and implementing a self-regulating system of quality control. However, the government has added a special element to this system that, again, shows the government wish to keep an eye on the higher education system. The WHW introduced a government inspectorate for higher education (an agency which, before 1993, did not exist for the universities). The inspectorate has been given the task of "meta-evaluation", i.e. the evaluation of the procedures and outcomes of the quality control system. In addition the inspectorate can, if needed, organize its own quality assessment procedures. An important aspect of the tasks of the inspectorate is to advise the minister on the results of follow-up actions undertaken by institutions after the outcomes of a self-organized assessment have shown that the quality of certain programs need extra attention. If the inspectorate judges those results to be insufficient, the minister may eventually decide to stop the funding of these programs. In practice, such decisions have not yet been taken, although in several cases the minister has threatened to do so.

The autonomy of the higher education institutions has most clearly been increased in the context of the so-called secondary (or support) processes (facilities, financial management, personnel management, administration).

The HBO-institutions (from 1 January 1994 on) and the universities (from 1 January 1995 on) have been given full ownership of their buildings and facilities. The institutions, of course, also assume responsibility for the costs of maintenance.

Higher education institutions may contract loans and to establish mortgages. Institutions can also be declared bankrupt, a potential danger which has stimulated the Ministry to consider whether the yearly financial accounts by the institutions should be elaborated.

In respect of conditions of employment of their personnel, the higher education institutions clearly are less dependent on government. The HBO-institutions have been free to negotiate fringe benefits with the labor unions since 1993. The universities have had this opportunity since January 1996. An independent committee has recently advised the minister to further enlarge autonomy of the institutions in the area of personnel management. Eventually universities and $\mathrm{HBO}$-institutions will be allowed to act as fully fledged employers and that their personnel will lose civil service status.

Finally, in the recent HOOP (1996), the minister indicated that the higher education institutions will have more scope to design their own governance and administrative structures and processes. Moreover, the government has indicated that it wants to strengthen the management capacities of the institutions, especially at central and middle urganizational levels.

The years since the HOAK policy document of 1985 show that government strategy towards higher education in the Netherlands still is a combination of two coordinating mechanisms of planning and market. Given so, in several aspects of the dynamics of the higher education system, while the government apparently wants to create or stimulate market-like arrangements, it also wants to retain its privilege to steer and control. Government claims for itself the task of guiding the system and of protecting it from potentially negative impacts. What could be the reasons for this self-proclaimed rolc of guardian?

\section{MARKET AND NON-MARKET FAILURES}

By combining the coordination of mechanisms both of planning and the market, the new strategy towards higher education can be seen as a deliberate attempt by 
government to address (and solve?) both market and non-market failures. Market failures are the well-known shortcomings of markets when confronted with certain goods and conditions. Welfare economics provides a number of suggestions and guidelines for government intervention to remedy these shortcomings (Samuelson, 1954; Musgrave, 1959; Davis and Hewlett, 1977). Non-market (or government) failures have received less theoretical attention in the literature (although public choice theory certainly addresses them). Non-market failures are related to the imperfect performance of governments and public agencies in designing and implementing public policy.

I would like to argue that the new government strategy towards higher education in the Netherlands is a more or less balanced combination of remedies to solve (or at least alleviate) both categories of failures. On the one hand, government interventions are assumed to be necessary to address the dynamics of imperfect markets. On the other hand, the mechanism of market coordination is strengthened to stimulate the higher education system to become more adaptive and innovative. Let us briefly explore the two concepts of market and non-market failures, to find out (in the next section of this article) how this balance between the two basic coordination mechanisms (planning and the market) is designed.

In economic theory (especially welfare economics) the predictable shortcomings of markets are clearly presented. Market failures are usually categorized as the shortcomings of markets when confronted with public goods, externalities, increasing returns to scale and "market imperfections" of various kinds. These shortcomings are seen as failures because they lead to outcomes that depart from Pareto-efficiency. In addition, outcomes in terms of social inequity are sometimes counted as market failure. This category of failure is related not so much to inadequate efficiency as to the inability to produce distributional equity.

When economic activities create external benefits or costs, the market is not completely efficient. External benefits and costs are not addressed in the decisions regarding the production of the goods that show these externalities, which leads to either too little (in the case of benefits) or too much (in the case of costs) production. Public goods can be seen as an extreme case of private goods having very large externalities. In the case of public goods the nonappropriable benefits or costs are offered to all actors confronted with these goods.

Higher education and scientific research (the two main activities in a higher education system) are clear examples of activities yielding positive externalities to society, hence providing a rationale for government intervention. The argument in the case of (higher) education are usually found in the presumed economic, moral, social and ethical benefits for the public at large, above and beyond the private benefits for the direct consumers. The argument in the case of scientific research usually indicates that the benefits of the production of knowledge and technology are nonappropriable by the organizations that would bear the associated costs, and hence that without government intervention the investments in research would be too low. In both cases the positive externalities suggest a role for government, through subsidies, and direct public sector production or regulation, to compensate for the shortcomings of the market.

The market failures related to increasing returns (and decreasing marginal costs) imply the tendency of a free market to form monopolies, thus producing inefficient outcomes. Also this shortcoming of the market provides a rationale for government intervention, either through direct regulation of the monopolies (by setting prices or 
allowable rates of return) or through the protection of consumers (e.g. through antitrust legislation).

Completely private systems of higher education and scientific research tend to imply this type of market failure. In public systems this type of market failure is not directly found, although the absence of competition between higher education institutions may come close to the forming of monopolies or oligopolies and hence trigger government intervention.

"Market imperfections" form another category of market failures. These imperfections may appear when prices do not reflect relative scarcities, when information about goods and market conditions are insufficiently or unequally available to consumers and/or producers, or when producers are unable to respond to market information because of the limited mobility of production factors. In these cases the market will again be inefficient, providing a rationale for governments to try to reduce these imperfections, for instance, by facilitating information or by lowering barriers to mobility.

Higher education and scientific research can be confronted with market imperfections. Especially insufficient information for consumers (for instance about differences in educational programs from different universities) may lead to government policy or regulation, as is clearly shown by the pressure by many governments to stimulate higher education institutions to provide information by means of quality assessment systems.

The distributional outcomes of markets sometimes are judged to be ethically or socially unacceptable and therefore are interpreted as a special category of market failures. In this sense even perfectly functioning markets can be criticized for their distributional effects and government intervention can be called for to remedy them.

Distributional equity often is a reason for governments to intervene in higher education systems. Through tax systems or redistributive expenditure programs (such as student loan programs) governments, for instance, try to create conditions of less inequality for the large group of potential consumers of higher education.

As was mentioned before, non-market (or government) failures are far less clearly presented in the literature than market failures. An important contribution to the discussion on non-market failures is provided by Wolf (1993).

Wolf (1993) categorizes these failures into four principal groups: the disjunction between costs and revenues, "internalities" and organizational costs, derived externalities, and distributional inequities.

The predominant non-market failures, according to Wolf, are related to the fact that government interventions often remove the link between the costs of producing a good (or of conducting an activity) and the income that sustains it. The absence of this link (which of course are the real prices that should be paid) leads to overproduction at the market and/or inefficient production, and hence to redundant and rising costs

In higher education systems the absence of real price links may result in redundant and rising costs because higher education institutions may be inclined to increase their output (and their production facilities) without a clear assessment of the incremental costs.

A second category of non-market failures concerns the lack of direct (market related) performance indicators for many public agencies leading them to develop their own output standards. These standards or "internalities" usually cannot be more than proxies. In addition, they usually lack the feedback from the consumers at 
the market, as well as from the competition with other producers. The result is again a tendency towards costs - inflation and inefficient production processes.

In higher education systems the output standards generally have the characteristics of non-direct performance indicators which, certainly when market conditions are limited, may indeed create inefficiencies.

A third category of non-market failures is the unanticipated side effects that may be the effect of government interventions. When governments try to compensate for one or more market failure, they often produce unforeseen side effects, with either negative or positive results for the overall efficiency of the system.

In higher education systems unanticipated effects are regularly found, for instance in the unforeseen shortages or surpluses of the labor market, as the result of manpower planning efforts.

A related and final category of non-market failures consists of the distributional inequities that are generated by the governmental activities that are undertaken to remedy the inadequacies of the performance of the market.

This category of failures also exists in higher education. An example is found in the redistributive effects of student loan programs to which middle income students may have more access than lower income students whom the loans are intended to benefit.

\section{THE WISH TO SOLVE BOTH TYPES OF FAILURES}

The governmental strategy towards higher education in the Netherlands, developed on the foundations of the HOAK policy document, can be seen as a mixed bag of policies and instruments to address both market and non-market failures.

The Dutch government clearly wants to stimulate the coordinating capacities of the market in the higher education systenn. It intends to strengthen the relationships between the producers and the consumers of higher education, hoping to increase the adaptability of the overall higher education system to the needs of society. In order to try to reach this objective, the government has increased the autonomy and responsibility of the higher education institutions. It also is trying to stimulate the consumers' sovereignty, especially by means of the procedural conditions it has formulated with respect to the self-regulatory quality control system (which should help both students and employers to be better informed about quality differences in the supply side of the system).

The government also appears to be aware of potential market failures. In several publications the Ministry of Education and Science has argued that higher education and scientific research yield important positive externalities to society, hence providing important rationales for government subsidies and regulation. The Ministry has also indicated that it would like to see more competition between higher education institutions instead of the oligopolitic tendencies that appear to be prevalent under the present conditions. The wish to improve the level of information for consumers, and to stimulate the institutions to react more flexibly to societal needs are also examples of the government's awareness of market failures. In addition the government for many decades now sees as its task to make higher education accessible to as large a clientele as possible.

The conviction that market failures exist in higher education appears to be the major motivation for the Dutch government to hold on to the planning coordination 
mechanism. The wish to stimulate the positive externalities of higher education, to protect its consumers, to spur on the competition between its producers, and to create distributional equity, are central elements in the new government strategy.

The non-market failures also are recognizable in the point of view of the government. Again and again the Ministry of Education and Science has indicated that the production of higher education should become more efficient, and that redundant and rising costs should be driven back. In addition, the Ministry has tried to stimulate the construction of more or less objective performance indicators.

However, these arguments apparently have not convinced the government that, in order to reach these objectives, it could further intensify the capacities of market coordination. Rather, the government appears to put faith in its own planning capabilities, placing authority in the hands of the Ministry to control the dynamics and outcomes of the overall higher education system.

The government wants to address (and solve) both market and non-market failures in the higher education system of the Netherlands. In order to do so it has developed an interesting new strategy towards higher education. However, in this strategy the emphasis, to a large extent, is still put on the mechanism of governmental planning. Instead of trying to further improve market-like conditions, for instance, by introducing a student voucher system (Friedman, 1962, Chap. 6) and by securing interinstitutional competition, the government has chosen to continue to regulate the behavior of the various categories of actors in the system with instruments of central steering.

\section{CONCLUSION}

The government appears to be well aware of the market failures and even some non-market failures related to higher education. But the conclusion that it has drawn, so far from the existence of these categories of failures, is that it needs to apply a strategy towards higher education in which the combination of planning and market coordination allows a substantial governmental influence on the dynamics of the higher education system. Apparently government is less impressed by the potential non-market failures of the unanticipated effects (including distributional inequities) of government intervention.

The new government strategy towards higher education makes it clear that the importance of market coordination has grown in Dutch higher education. $\Lambda t$ the same time the elaboration of this strategy demonstrates that the coordinating capacities of the market are not used to their full strength. The government has worked out a careful balance of market and planning coordination, in which it has not yet abandoned its confidence in its own capacity to successfully steer a highly complex system.

\section{REFERENCES}

Aldrich, H. E. (1979) Organizations and Environments. Prentice-Hall, Englewood Cliffs, N. J. Ashby, W. R. (1956) An Introduction to Cybernetics. Chapman \& Hall, London.

Birnbaum, R. (1983) Maintaining Diversity in Higher Education. Jossey-Bass, San Francisco.

Camps, T. W. A. (1984/5) De omgekeerde processie van Echternach (The backward procession to Echternach). Universiteit en Hogeschool 31, 21-28.

Cohen, A. (1982) An historical overview of the state and higher education in the Netherlands. European Journal of Education 17,271-281. 
Davis, J. R. and Hewlett, J. R. (1977) An Analysis of Market Failure: Externalities, Public Goods, and Mixed Goods. University of Florida Press, Gainesville.

Faludi, A. (1973) Planning Theory. Pergamon Press, Oxford.

Ferguson, A. (1996) An Essay on the History of Civil Society (orig. 1767). Cambridge University Press, Cambridge.

Florax, R. J. G. M. (1992) The University: A Regional Booster? Economic Impacts of Academic Knowledge Infrastructure. Avebury/Ashgate, Aldershot.

Friedman, M. (1962) Capitalism and Freedom. The University of Chicago Press, Chicago.

Goedegebuure, L. C. J., Maassen, P. A. M. and Westerheijden, D. F. (eds) (1990) Peer Retiew and Performance Indicators. Lemma, Utrecht.

Hannan, M. T. and Freeman, J. (1977) The population ecology of organizations. American Journal of Sociology 82, 929-964.

Hannan, M. T. and Freeman, J. (1989) Organizational Ecology. Harvard University Press, Cambridge.

Hayek, F. A. (1967) Studies in Philosophy, Politics and Economics. Routledge \& Kegan Paul, London.

Huisman, J. and Jenniskens, I. (1994) The role of the Dutch government in curriculum design and change. European Journal of Education 29, 269-279.

Maassen, P. A. M. and van Vught, F. A. (1988) An intriguing Janus-head: the two faces of the new governmental strategy for higher education in the Netherlands. European Journat of Education 23,65. 77.

Mannheim, K. (1940) Man and Society in an Age of Reconstruction. Routledge \& Kegan Paul, London.

Mertens, F. J. H., Paardekooper, C. M. M., de Vijlder, F. J. (1988) Over de betekenis van de dichotomie plan/markt voor het hoger onderwijsbeleid (On the usefulness on the planning/market dichotomy for higher education policy). Tijdschrift voor Hoger Onderwijs 6, 126-140.

Ministry of Education and Science (1985) Hoger Onderwijs: Autonomie en Kwaliteit (Higher Education: Autonomy and Quality). Zoetermeer.

Ministry of Education and Science (1987) Hoger Ondemijs en Onderzoek Plan: Kerndocument (Higher Education and Research Plan: Core Document). Zoetermeer.

Ministry of Education and Science (1993) Wet op het Hoger Onderwijs en Wetenschappelijk Onderzoek (Higher Education and Scientific Research Act). Staatsuitgeverij, 's-Gravenhage.

Mitnick, B. M. (1980) The Political Economy of Re'gulation: Creating, Designing and Removing Re'gulatory Reforms. Columbia University Press, New York.

Musgrave, R. (1959) The Theory of Public Finance. McGraw-Hill, New York.

Pfeffer, J. and Salancik, G. R. (1978) The External Control of Organizations. Harper \& Row, New York.

Samuelson. P. A. (1954) The pure theory of public expenditure. Revien of Economics and Statistics 36, $387-389$.

Sowell, T. (1980) Knowledge and Decisions. Basic Books, New York.

van Vught, F. A. (1987) Plan-en Markteoürdinatie in het Hoger Onderwijs (Planning and Market Coordination in Higher Education). CHEPS, Enschede.

van Vught, F. A. (1989) Argumenten gevraagd voor plancoördinatie in het hoger onderwijs (Arguments requested for the use of planning in higher education). Tijdschrift voor Hoger Onderwijs 7, 28-34.

van Vught, F. A. (1993) Governmental Strategies and Innovation in Higher Education. Kingsley, London.

van Vught, F. A. (1994) Policy models and policy instruments in higher education. In Higher Education: Handbook of Theory and Research, ed. J. C. Smart, Vol. X, pp. 88-125. Agathon Press, New York.

van Vught, F. A. and Westerheijden, D. F. (1993) Quality Management and Quality Assurance in European Higher Education. Office for Official Publication of the European Commission, Luxembourg.

Vroeijenstijn, T. (1995) Improvement and Accountability: Navigating Between Scylla and Charybdis. Kingsley, London.

Vroeijenstijn, T. and Acherman, II. (1990) Control oriented versus improventent oriented quality assessment. In Peer Review and Performance Indicators, eds L. C. J. Goedegebuure, P. A. M. Maassen and D. F. Westerheijden, pp. 81-101. Lemma, Utrecht.

Westerheijden, D. F., Brennan, J. and Maassen, P. A. M. (eds) (1994) Changing Contexts of Quality Assessment. Lemma, Utrecht.

Wildavsky, A. (1979) Speaking Truth to Power: The Art and Craft of Policy Analysis. Little, Brown, Boston.

Wolf, C. (1993) Markets or Governments, Choosing Between Imperfect Alternatives. The MIT Press, Cambridge, Mass. 